\title{
Structural Features of the Leaf and Fruit of the Emerald Variety Olea europaea L., Growing under the Introduction Conditions of Surkhandarya
}

\author{
Sodikjon Kh. Abdinazarov, Guljan M. Duschanova \\ Tashkent Botanical Garden Named after Acad. F.N. Rusanova at the Institute of Botany of the Academy of Sciences of the \\ Republic of Uzbekistan, Tashkent, Uzbekistan \\ Email: guljon.duschanova@mail.ru
}

How to cite this paper: Abdinazarov, S.Kh. and Duschanova, G.M. (2020) Structural Features of the Leaf and Fruit of the Emerald Variety Olea europaea L., Growing under the Introduction Conditions of Surkhandarya. American Journal of Plant Sciences, 11, 554-563.

https://doi.org/10.4236/ajps.2020.114040

Received: February 22, 2020

Accepted: April 21, 2020

Published: April 24, 2020

Copyright $\odot 2020$ by author(s) and Scientific Research Publishing Inc. This work is licensed under the Creative Commons Attribution International License (CC BY 4.0).

http://creativecommons.org/licenses/by/4.0/

\section{(c) (i) Open Access}

\begin{abstract}
For the first time, the anatomical structure of the leaf, petiole and fruit of the emerald variety Olea europaea, which grows under the conditions of introduction in the Oltinsay district of the Surkhandarya region of Uzbekistan, was studied. The following characteristic diagnostic features were determined: in the leaf-the dorsiventral type of leaf mesophyll; thick-walled outer walls of the epidermis; slightly sinuous outlines of the cells of the adaxial epidermis, rectilinear-abaxial; hypostomotic leaves; non-submerged stomata of the anomocytic type; thyroid silver-gray and white-fluffy star-shaped squamous-numerous on the adaxial epidermis than on the adaxial; chlorophyll-bearing palisade and spongy parenchyma; closed collateral type of conductive bundles; the most scleralized leaf due to the presence of filamentous scleroids in it (long, thin, resembling fibers); in the petiole-parenchymal-beam type of structure; the location of the angular collenchyma under the epidermis; closed collateral type of conductive bundles; the presence of thick-walled parenchymal cells and the presence of filiformscleroids; pericarp of the fetus consists of a rigid 1-layer exocarp, parenchymal mesocarp, and sclerenchymal endocarp; the presence of scleroids-stony cells and branched sclerenchymal fibers with drops of oil in the parenchymal cells. Diagnostic signs revealed by us reflect xeromorphic of this species. All the signs were compared, and we came to the conclusion that the anatomical signs of the leaf and the fetus can be useful for providing diagnostic signs for distinguishing the studied taxa, can be used in taxonomy, and can serve to identify plant materials.
\end{abstract}




\section{Keywords}

Anatomy, Leaf, Petiole, Pericarp of the Fetus, Olea europaea, Surkhandarya Region, Uzbekistan

\section{Introduction}

Species of the genus Olea are evergreen trees and shrubs of the Oleaceae family, known primarily for one species, Olea europaea L., an oilseed plant widely cultivated since antiquity.

According to Yermatova D. E. [1], olive plants for 20 centuries of civilization were not grown in conditions not only in Uzbekistan, but also in Central Asia. One of the new acclimatized plants is Olea (olive). There is every reason to assert: the olive, being the "native" of the hot subtropical climate, could easily register with us too. The experiments began in the Syrdarya region of the Gulistan region, in Andijan region 3 thousand, Surkhandarya region 15 thousand two-year-old seedlings. Brought seedlings from the Crimea and Turkey took root well on medium saline soil.

Many researchers paid attention to the study of frost resistance of olives: V. I. Alekseev [2], A. F. Jeanov [3], C. M. Shamtsyan [4], E. N. Domanskaya [5], E. N. Domanskaya, L. M. Vasilenko [6], V. A. Sholokhov, E. N. Domanskaya [7], V. G. Abdullaev [8], G. T. Gutiev [9]. According to some authors, the critical temperature for olives ranges from $-8^{\circ}-10^{\circ}$, leaves and shoots are damaged at a temperature of $-17^{\circ} \mathrm{C}-22^{\circ} \mathrm{C}$, with complete death of the plant or freezing to the root neck.

According to A. A. Rzhevkina [10], partial damage or complete death of leaves and buds in olives, depending on the variety, is observed at a temperature of $-14^{\circ} \mathrm{C}-17^{\circ} \mathrm{C}$ and the death of the whole aerial part of the tree with short-term temperature drops to $-20^{\circ}-21^{\circ}$ or lower.

According to S. I. Petyaeva [11] olives are slightly damaged at a temperature of $-13^{\circ}-15^{\circ}$, and freeze to the root at $-17^{\circ}-20^{\circ}$. Not only winter colds, but also spring frosts are dangerous for olives.

So, with morning frosts of $-3^{\circ}-4^{\circ}$ young leaves and even the tops of olive shoots are often damaged. Olive flowers suffer already at $-1^{\circ}-2^{\circ}$. Fruits are damaged at about $-3^{\circ}-5^{\circ}$ depending on the variety, degree of maturity and other conditions. Approximately such critical temperatures at which plants die are determined by I. A. Zhigarevich [12].

Olive fruits are rich in fats-up to $80 \%$ by dry weight of pulp. The fruits also contain other important nutrients: proteins, sugars, pectin [13]-[18].

An equally important component of the pulp of olive fruits is ash substances, in which alkaline elements predominate, which play a role in maintaining the acid-base balance in human blood: potassium $-82 \%$ of the total amount of all alkaline ash elements, sodium and calcium -7.5 each \%, magnesium $-0.18 \%$ of 
iron-about $1 \%$. The fruit pulp contains a complex of vitamins valuable for the body: provitamin $\mathrm{A}$ - up to $2.5 \mathrm{mg}$, vitamin $\mathrm{C}-$ from 8 to $13 \mathrm{mg}$, a group of vitamins $\mathrm{B}, \mathrm{P}$-active substances. Due to the oleuropein glycoside contained in fruits from $2 \%$ to $10 \%$, which gives them a bitter taste. In the fresh form, they are inedible. Various types of products obtained as a result of processing olives have high nutritional and taste qualities [11] [12] [19].

Olive fruits are widely used for canning, mainly for salting. The main types of salted olives are: dry olives without brine, black olives in brine and green olives. Dry olives in oil or without oil serve as food for the population of the southern regions of the Soviet Union, the Balkans, Greece, Spain, Italy, Lebanon, Morocco, America, Tunisia and Turkey [20].

The anatomical structure of the leaf and fruit of the emerald variety Olea europaea has not been studied in Uzbekistan. This determines the relevance and novelty of our research.

The aim of our research is to study the anatomical structure of the leaf and fruit of the emerald variety Olea europaea, with the aim of determining diagnostic features and localizing biologically active substances in organs and tissues.

\section{Material and Methods}

The object of the study is a perennial evergreen shrub or tree of the emerald variety Olea europaea of the genus Olea from the Oleaceae family, growing under the conditions of introduction of the Oltinsay district of the Surkhandarya region of Uzbekistan (Figure 1). The material was collected 2018-2019 in the conditions of introduction of the Altynsay district of the Surkhandarya region at an altitude of $551 \mathrm{~m}$ above sea level. m. $38^{\circ} 11^{\prime} 48^{\prime \prime S}$. $67^{\circ} 41^{\prime} 42^{\prime \prime} \mathrm{W}$ c. d. The central and southern parts of the Surkhandarya region are flat. The Gissar Range is located in the north of the Surkhandarya Region, its spurs are located in the west and northwest-the Baysuntau Mountains (4425 m) and Kugitangtau (3139 m),

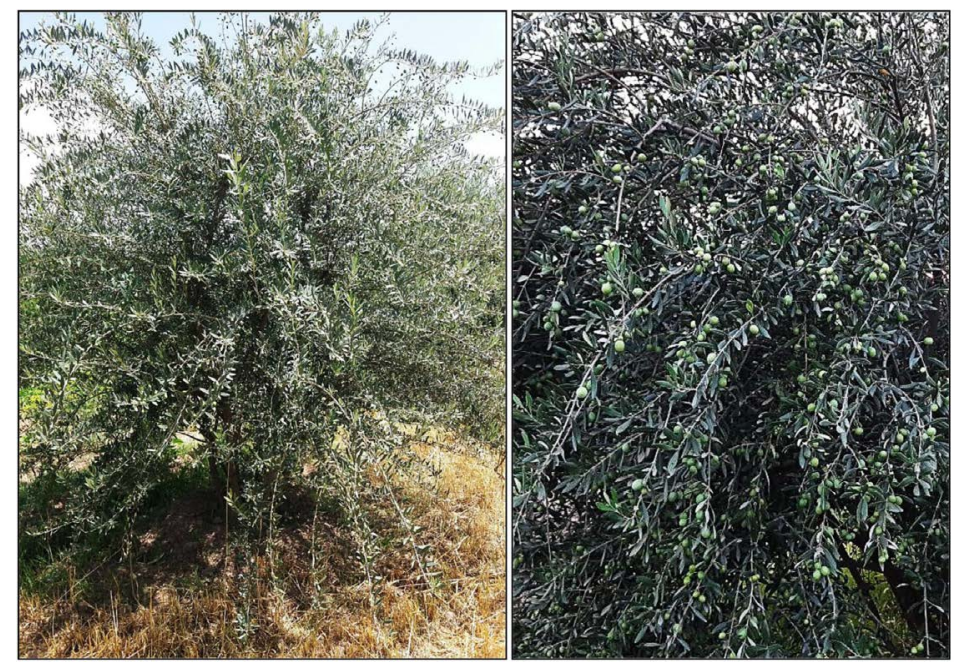

Figure 1. Appearance of emerald variety Olea europaea in the fruiting phase. 
in the east is the Babatag ridge (up to $2290 \mathrm{~m}$ ), in the south - the Amudarya river valley. Climate-from dry desert in the south to subtropical in the north. The average temperature in January is $+3^{\circ} \mathrm{C}$, in July- $+30^{\circ} \mathrm{C}$. On the plains, rainfall ranges from $130 \mathrm{~mm}$ to $360 \mathrm{~mm}$ per year, in foothills-from $440 \mathrm{~mm}$ to $620 \mathrm{~mm}$.

The leaf and fetus were fixed in $70^{\circ}$ ethanol for anatomical study. A manual method was used to prepare slices of the vegetative organs. The epidermis was studied on paradermal and transverse sections. Paradermal sections of the epidermis of the leaf are prepared manually using tweezers. Cross sections of the leaf and the fruit are prepared manually using a safety razor. Cross sections of the leaf are made through the middle, the fruit is serially. Sections were stained with methylene blue, followed by gluing in glycerol-gelatin [21]. Descriptions of the main tissues and cells are given according to C. Esau [22], N. S. Kiseleva [23], M. A. Plisko [24] and epidermis-according to S. F. Zakharevich [25]. Microphotographs were taken with a Canon A123 digital camera microphotograph with a Motic B1-220A-3 microscope.

\section{Result and Discussion}

The leaf is a vegetative organ of the plant, performing the function of photosynthesis, transpiration and gas exchange. The leaves of the emerald cultivar O. europaea are opposite, lying crosswise, usually lanceolate, spiky, less blunt or hollow, whole-edged, with slightly curved edges, protruding, leathery, dark green above, glabrous, with rare thyroid star-like whitish squama, silvery-gray underneath or rusty brown from thick numerous squama.

On the paradermal section, the outlines of epidermal cells are slightly sinuous, the projection is polygonal and chlorophyll-bearing. However, the upper epidermis is somewhat different from the lower epidermis.

The cells of the upper epidermis are larger and slightly sinuous, the cells of the lower epidermis are small and rectilinear. On the adaxial and abaxial epidermis there is thyroid star-shaped squama. On the abaxial side of the epidermis, silver-gray, white-fluffy or rusty-brown from thick squama are numerous than on the adaxial side (Figure 2).

Hypostomatic leaves-stomata are located on the abaxial (lower) side of the epidermis of the leaf blade and are transverse to the longitudinal axis of the leaf. All this leads to a reduction in water loss from the surface of the sheet. The shape of the stomata is round-oval (Figure 2 and Figure 3).

The closing stomata cells on both sides of the leaf are almost the same length. The stomata are submerged, of an anomocytic type.

Leaf mesophyll on the cross section of the dorsiventral type, which is represented by palisade cells located under the upper epidermis of the leaf mesophyll, spongy cells-above the lower epidermis of the leaf mesophyll. The epidermis is represented by one row of cells with a thick-walled cuticle layer. Adaxial epidermal cells are larger than abaxial. Between the adaxial and abaxial epidermis is an assimilation tissue consisting of palisade and spongy cells. Under 


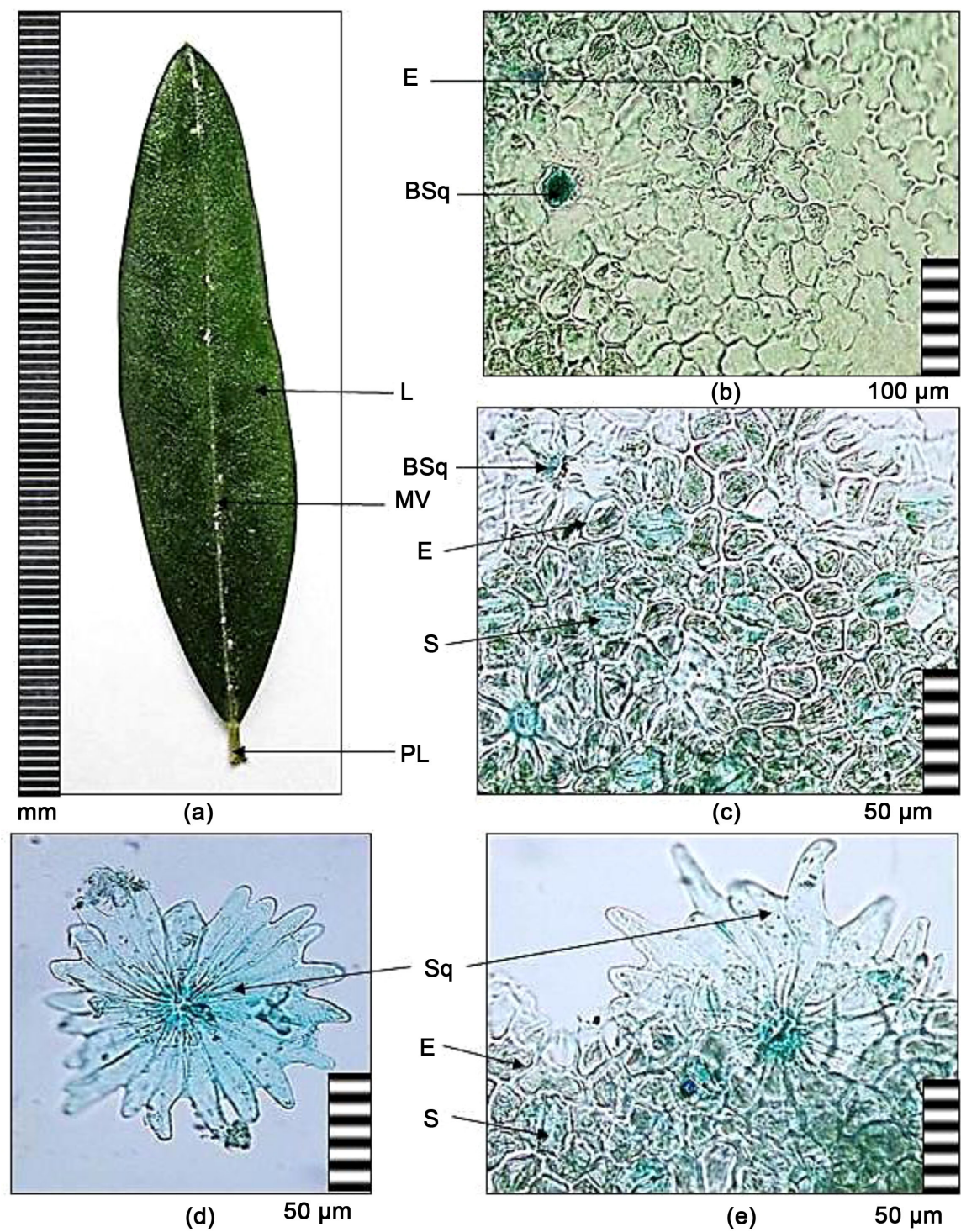

Figure 2. Morpho-anatomical structure of the epidermis of the leaf of the emerald variety Olea europaea in the paradermal section: (a) general view of the leaf, (b) adaxial epidermis; (c)-(d) abaxial epidermis; (e) squama. Legend: BSq-the base of the squama, E-epidermis, L-leaf, MV - the main vein of the leaf, PL-petiole of leaf, S-stomata, Sq-squama. Magnification-50 - 100 micron and $\mathrm{mm}$.

the adaxial epidermis is the palisade parenchyma. The palisade parenchyma is chlorophyll-bearing, large and more elongated, which consists of three rows of cells and is located between the adaxial epidermis and the spongy parenchyma of the leaf (Figure 3). The spongy chlorophyll-bearing parenchyma consists of 7 - 8 rows and is located between the palisade parenchyma and the abaxial epidermis. The spongy parenchyma is round, small-cell with large cavities and intercellular spaces. Between palisade and spongy cells there are numerous lateral conducting bundles, with 3 - 4 small vessels. Among the spongy cells, numerous filamentous scleroids were found, long, thin, resembling fibers. The main leaf vein extends on the abaxial side. Under the adaxial epidermis of the leaf, a 1 - 3-row angled 


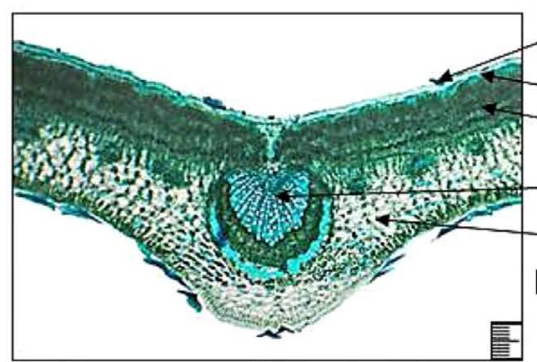

(a)

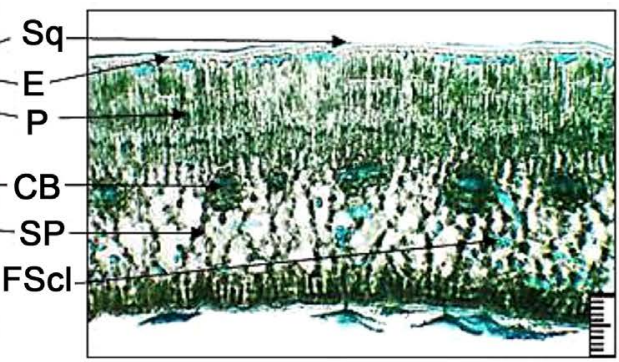

(b)
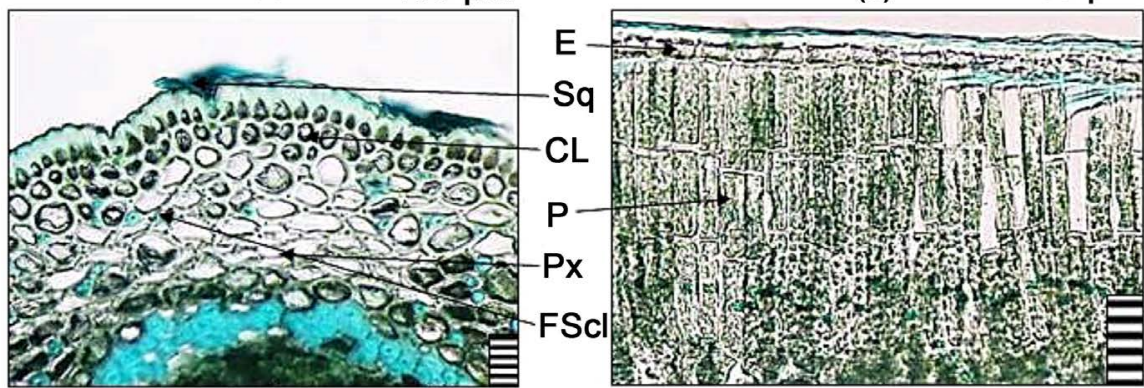

(c)

50 MKM

(d)

$50 \mu \mathrm{m}$

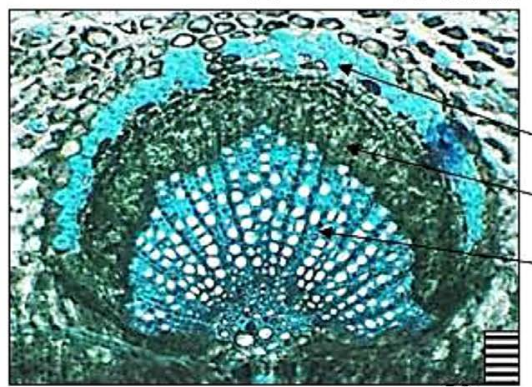

(e)

$50 \mu \mathrm{m}$
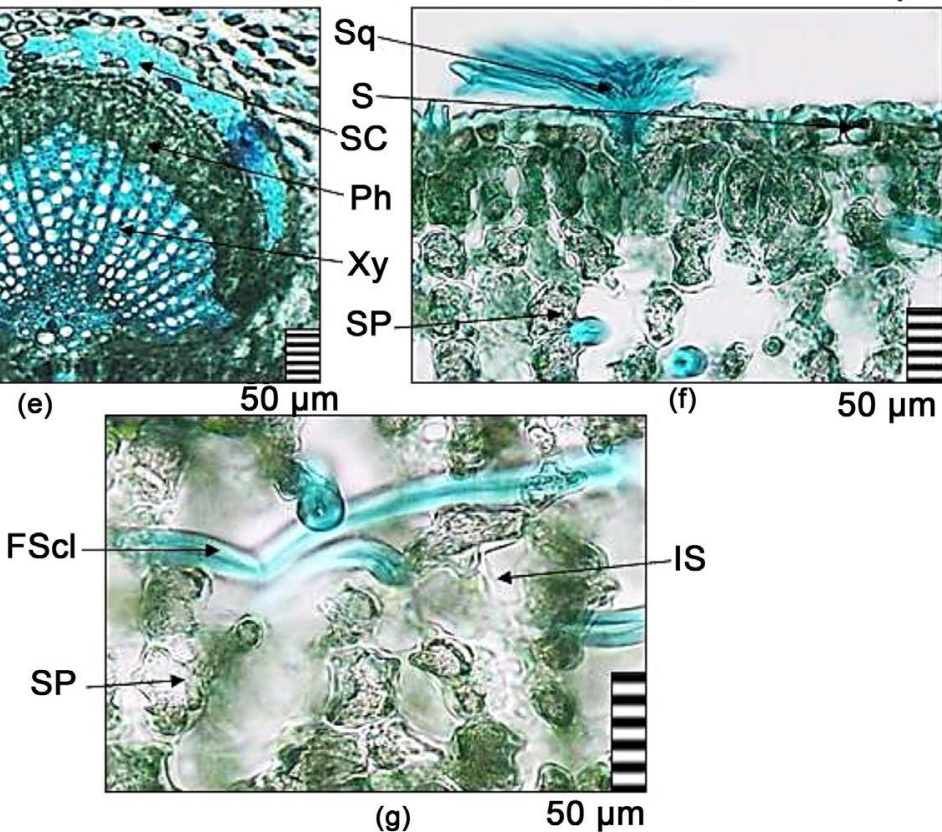

(g)

$50 \mu \mathrm{m}$

Figure 3. Anatomical structure of the mesophyll of the leaf of the emerald variety Olea europaea in cross section: (a) general view of the main vein of the leaf; (b) mesophyll leaf; (c) epidermis and collenchyma of the main vein of the leaf; (d) palisade parenchyma; (e) conductive beam; (f) spongy parenchyma, unloaded stomata and squama; (g) filiform scleroids in the mesophyll of the leaf. Legend: $\mathrm{CB}$-conductive bundle, $\mathrm{CL}-$ collenchyma, E-epidermis, FScl-filamentous scleroids, IS-intercellular spaces, $\mathrm{P}$-palisade parenchyma, $\mathrm{Ph}-$ phloem, S-stomata, SC-sclerenchyma, SP-spongy parenchyma, Sq-squama, Xy-xylem. Magnification-50 - 100 micron.

collenchyma is located (Figure 3). The rest of the vein is occupied by the main parenchyma, in which 1 conductive bundles is immersed, parenchyma cells are thick-walled, round-oval. Conductive beams of closed collateral type, consisting of phloem and xylem. Xylem thick-walled, rounded. Their walls are thickened in 
the form of spirals (Figure 3).

Petiole. Petiole of leaf on cross section of rounded-ribbed shape, parenchymal-beam type, consists of a single-row epidermis. Under the epidermis is a 5 6-row angled collenchyma. Under the collenchyma, 5 - 6 rows of thick-walled parenchymal cells are located. Among parenchymal cells numerous filamentous scleroids, long, thin, resembling fibers, were found. In the center of the petiole there is 1 conductive bundle. The conducting bundle is closed collateral, the ring-shaped and sclerified form due to sclerenchymal cells (Figure 4).

Fruit-single-seeded drupes, $2.5-3.0 \mathrm{~cm}$ long, with one bone and the shape of the fruit is from oblong to spherical, blunt or pointed, fleshy, green or whitish, reddish or purple, sometimes almost black, firm and green until ripe. Single-seeded fruits are characteristic of pyrenaria in the genus and species of $O$. europaea. Pyrenaria usually with fleshy pericarp. On the cross section of the pericarp of the fruit of the emerald variety $O$. europaea is the tissue that forms the pericarp, rather uniform-a rigid 1-layer exocarp, parenchymal mesocarp, and sclerenchymal endocarp. The exocarp is represented by slightly elongated in the radial direction, with granular contents, covered with a thick cuticle; the shape of

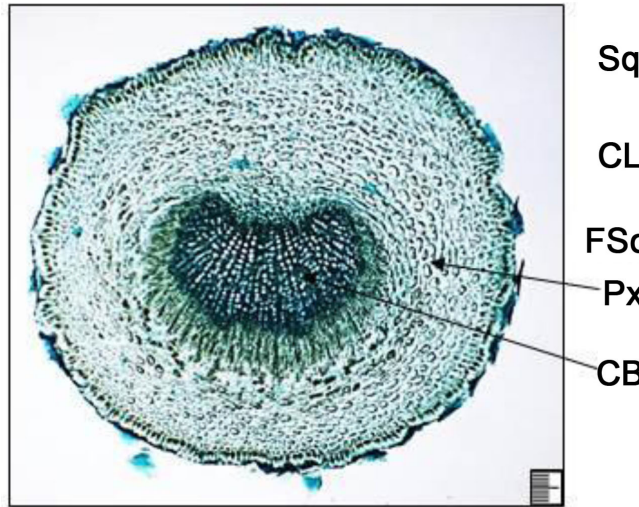

(a)

$100 \mu \mathrm{m}$

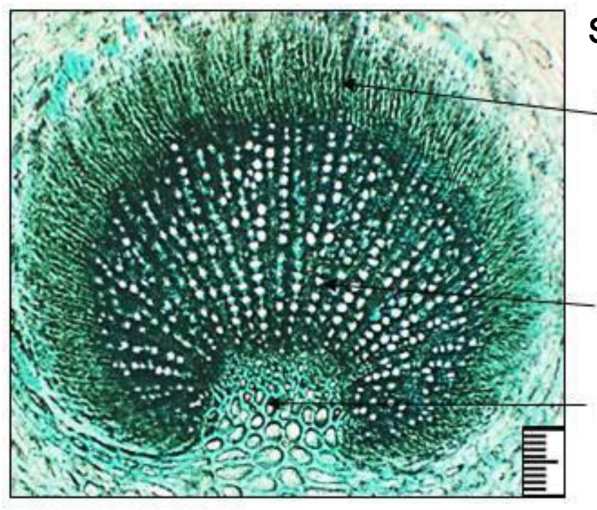

(c)

$100 \mu \mathrm{m}$

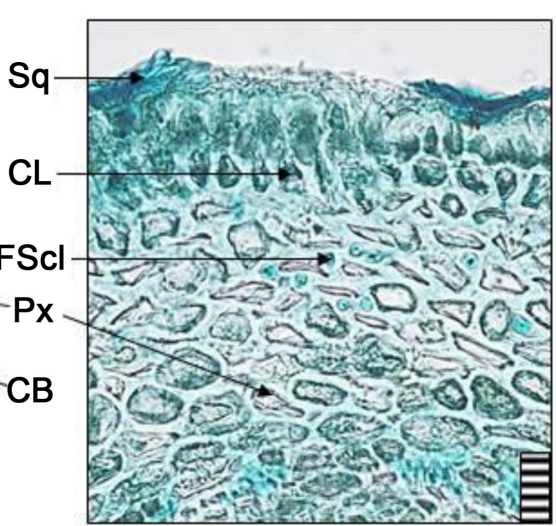

(b)
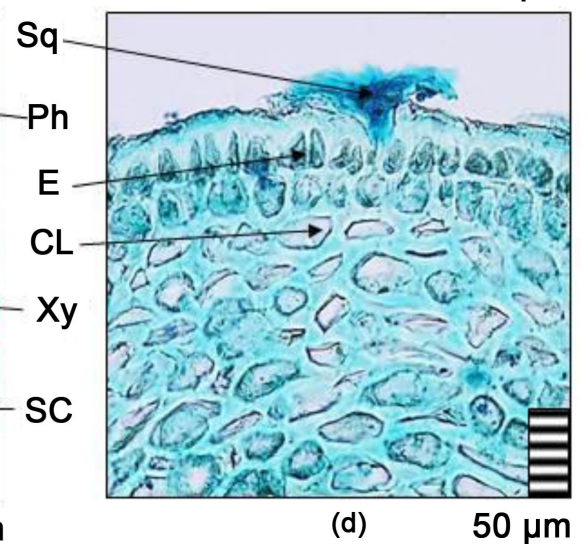

Figure 4. The structure of the leaf petiole of the emerald variety Olea europaea in cross section: (a) general view; (b), (d) epidermis, parenchyma and collenchyma; (c) conductive bundle. Legend: $\mathrm{CB}$-conductive bundle, $\mathrm{CL}$-collenchyma, E-epidermis, FScl-filamentous scleroids, $\mathrm{Px}$-parenchyma, $\mathrm{Ph}-$ phloem, SC-sclerenchyma, Sq-squama, Xy-xylem. Magnification-50 - 100 micron. 
the cells is polygonal from the surface. Mesocarp parenchymal, multilayer. In mesocarp, scleroids are also found-stony cells and branched sclerenchymal fibers. The parenchyma is filled with drops of oil. Endocarp is usually present, expressed to varying degrees, formed by stony cells and sclerenchymal fibers (Figure 5).

Thus, for the first time under the conditions of introduction of the Surkhandarya region, the morpho-anatomical structure of the leaf, petiole and fruit of

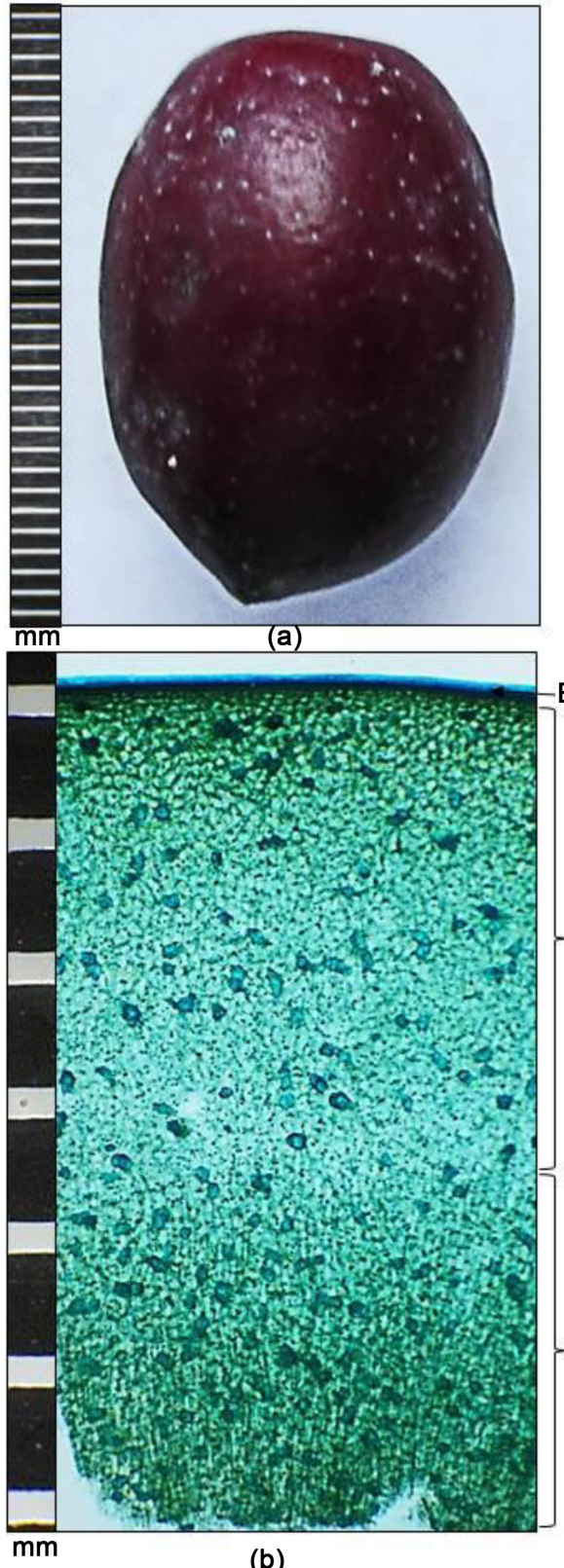

(b)

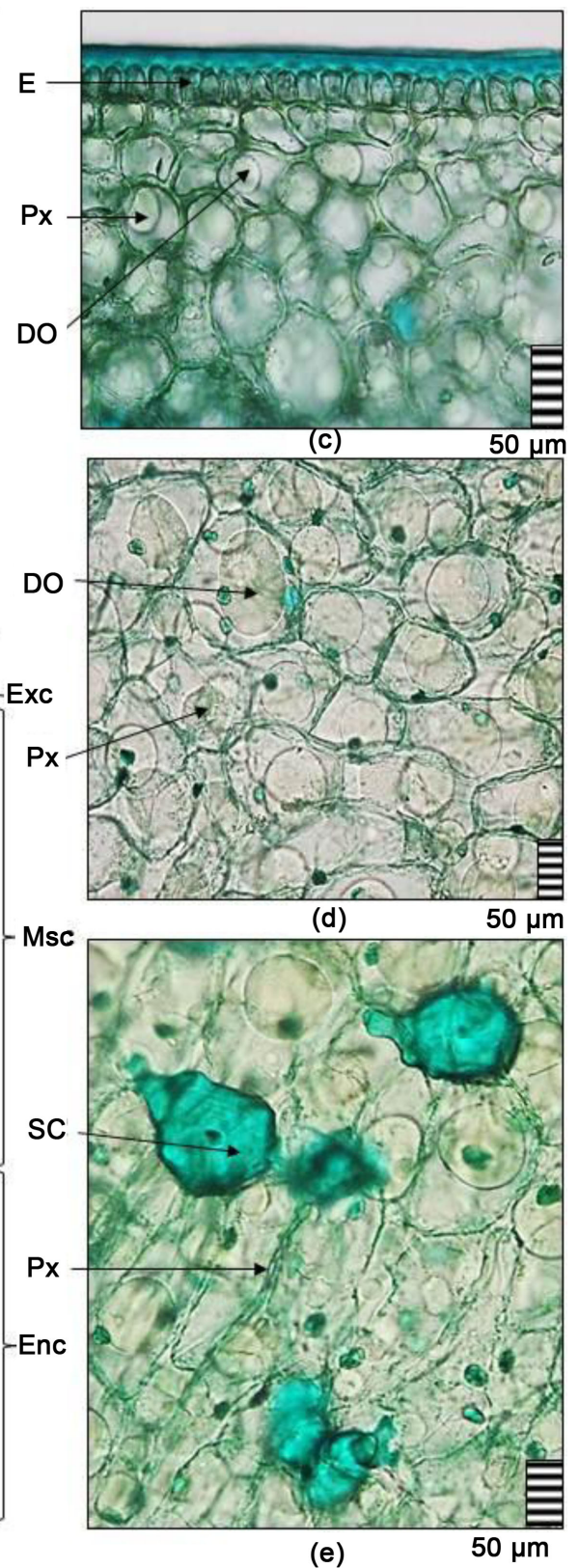

(e)

Figure 5. Morpho-anatomical structure of the pericarp of the fruit of the emerald variety Olea europaea in cross section: (a) general view of the fruit; (b) fetal pericarp; (c) exocarp; (d) mesocarp; (e) endocarp. Legend: DO-a drop of oil, E-epidermis, Exc-exocarpy, Enc-endocarpy, Msc-mesocarpy, Px-parenchymal cells, SC—sclerenchyma. Magnification-50 - 100 micron and $\mathrm{mm}$. 
the emerald variety $O$. europaea was studied. The following characteristic diagnostic features are identified: in the leaf-dorsiventral type of leaf mesophyll; thick-walled outer walls of the epidermis; slightly sinuous outlines of the cells of the adaxial epidermis, rectilinear-abaxial; hypostomotic leaves; non-submerged stomata of the anomocytic type; thyroid silver-gray star-shaped squama, white-fluffy, numerous on the adaxial epidermis than on the adaxial; chlorophyll-bearing palisade and spongy parenchyma; closed collateral type of conductive bundles; the most scleralized leaf due to the presence of filamentous scleroids in it, long, thin, resembling fibers; in the petiole-parenchymal-beam type of structure; the angular collenchyma is located under the epidermis; closed collateral type of conducting bundles, the presence of thick-walled parenchymal cells and the presence of filiformscleroids; pericarp of the fetus consists of a rigid 1-layer exocarp, parenchymal mesocarp, and sclerenchymal endocarp; the presence of scleroids-stony cells and branched sclerenchymal fibers.

Diagnostic signs revealed by us reflect xeromorphic of this species. When processing with a solution of methylene blue in the palisade, spongy and parenchymal cells, biologically active substances are found. In the parenchymal cells of the pericarp of the fetus, a drop of oil was noted. The results obtained made it possible to determine a number of morphological, anatomical, and characteristic diagnostic features for the studied species. These identified diagnostic signs can be used in taxonomy and can serve to identify plant materials.

\section{Conflicts of Interest}

The authors declare no conflicts of interest regarding the publication of this paper.

\section{References}

[1] Ermatova, D.E. (2016) Agricultural Technology of Olive in Uzbekistan. Science and Technology, Tashkent, 160-178.

[2] Alekseev, V.P. (1954) Olive. Olive Tree. Bulletin of VNIICHiSK, 4, 86-109.

[3] Jeanov, A.F. (1959) Experiments in Grafting European Olives in the Crown of Ash, Lilac and Privet. Proceedings of the State Nikitsky Botanical Garden, 29, 221-234.

[4] Shamtsyan, S.M. (1966) Physiological Characteristics of the Wintering of Some Varieties of Olives. Abstract. Diss. ... for the Competition. Scientist Degrees of Cand. Biol. Sciences, Tbilisi, 29.

[5] Domanskaya, E.N. (1973) To the Question of Determining the Respiratory Process in Olives in Connection with Its Frost Resistance. GNSS Bulletin, 3, 48-51.

[6] Domanskaya, E.N. and Vasilenko, L.M. (1984) The Redox Potential and Acidity of the Cell Juice of Olive Leaves in Connection with Its Winter Hardiness. Bulletin of the State Nikitsky Botanical Garden, 53, 77-82.

[7] Sholokhov, V.A. and Karakhanova, S.B. (1977) The Accumulation of Oil in Olives. Oil and Fat Industry, 3, 20.

[8] Abdullaev, V.G. (1976) Agroclimatic Resources of the Azerbaijan SSR Abstract. Diss. ... for the Competition. Scientist Degrees of Cand. Geographer. Sciences, Baku, 22. 
[9] Gutiev, G.T. and Mosiyash, A.S. (1977) Climate and Frost Resistance of Subtropical Plants. Gidrometizdat, Leningrad, 280.

[10] Rzhevkin, A.A. (1947) Olive Crops in the USSR. Publishing House Ministry of Agriculture of the USSR, Moscow, 62.

[11] Petyaev, S.I. (1951) Olive. Publishing House Pishchepromizdat, Moscow, 58.

[12] Zhigarevich, I.A. (1955) Olive Culture. Publishing House Selkhozgiz, Moscow, 246.

[13] Kamerinsky, A.M. (1941) Olive. Journal Science and Life, 5, 44-46.

[14] Kamerinsky, A.M. (1948) Olive and Its Reproduction. Bulletin of the Institute for Tea and Subtropical Crops, 1, 99-107.

[15] Zhigarevich, I.A. and Komarinsky, A.M. (1959) On the Possibility of Industrial Development in the USSR of Olive Culture and the Production of Salted Olives and Olive Oil. Subtropical Cultures, 4, 60-69.

[16] Zhigarevich, I.A. (1980) Agro Rules for the Cultivation of Olives. Baku, 49.

[17] Rasulov, M.R. and Atayan, S.S. (1965) Olives Are a Valuable Food Product. Canning and Vegetable Drying Industry, 8, 29-31.

[18] Rudenko, V.F. (1976) Olive. Chemistry and Life, 11, 88-93.

[19] Sholokhov, V.A. (1981) Selection of Olives in the Nikitsky Botanical Garden. Bulletin of the GNSS, 3, 63-66.

[20] Soyunov, P. and Seyidov, S. (2011) Economic Value of Olives. Young Scientist, 8, 167-170.

[21] Barykina, R.P., Veselova, T.D., Devyatov, A.G., et al. (2004) Handbook of Botanical Microtechnology (Basics and Methods). Publishing House Moscow State University, Moscow, 6-68.

[22] Esau, K. (1969) Plant Anatomy. Publishing House World, Moscow, 138-416.

[23] Kiseleva, N.S. (1971) Anatomy and Morphology of Plants. Publ. Higher School, Minsk, 89-119, 2015-227.

[24] Plisko, M.A. (2010) Families Oleaceae L. Comparative Anatomy of Seeds. Nauka, St. Petersburg, Vol. 7, 110-128.

[25] Zakharevich, S.F. (1954) On the Methodology for Describing the Epidermis of the Leaf. Vestnik LSU, Leningrad, 4, 65-75. 